\title{
Comunicação
}

[Communication]

\section{Minimal inhibitory concentration of azithromycin in Rhodococcus equi strains isolated from foals}

[Concentração inibitória mínima da azitromicina em linhagens de Rhodococcus equi isoladas de potros]

\author{
M.G. Ribeiro, A.C. Paes, F.J.P. Listoni \\ Faculdade de Medicina Veterinária e Zootecnia - UNESP \\ Caixa Postal 560 \\ 18618-000 - Botucatu, SP
}

\begin{abstract}
Rhodococcus equi ( $R$. equi) is a facultative intracellular Gram-positive organism that causes chronic pyogranulomatous pneumonia and enteritis in foals, mainly from 1 to 6 months-old (Giguère and Prescott, 1997). It is less frequently associated with others clinical signs in domestic species (Radostits et al., 2000; Takai et al., 2003). During the last years, the organism has emerged as an important opportunistic pathogen in immunosuppressed patients, especially those infected by the immunodeficiency virus (Severo et al., 2001). In Brazil, rhodococcosis is considered to be one the most important disease in foals (Ribeiro, 2005). Recently it has been described in human, including patient with aids (Severo et al., 2001). R. equi expresses different virulence factors, including intracellular maintenance in macrophages, presence of virulence-associated plasmids, and resistance to conventional antimicrobial therapy, which may lead to chronic infections difficult to be treated, and high mortality rates in foals (Takai, 1997; Ribeiro et al., 2002).
\end{abstract}

Improved survival rates in the treatment of foals have been obtained in last years with the association between rifampin and erythromycin (Giguère and Prescott, 1997). However, erythromycin presents a variable rate of absorption by oral route, requiring multiple daily doses and showing high incidence of undesirable collateral effects (Stratton-Phelps et al., 2000). Recently, azithromycin has been investigated as an alternative drug to erythromycin, due to high bioavailability and chemical stability, and because it reaches higher concentrations in tissues and alveolar macrophages (Tavares, 2000; Davis et al., 2002). The purpose of present study was to investigate the minimal inhibitory concentration of azithromycin in $R$. equi strains isolated from foals in Brazil.

A total of $42 R$. equi strains were used in this study. They were isolated from pyogranulomatous pneumonia (40 strains) (Fig. $1)$, bronchiolar lavage (1 strain) and mesenteric lymphadenitis (1 strain) obtained at the domestic animal infectious diseases sector at Faculdade de Medicina Veterinária e Zootecnia - UNESP Botucatu, SP, Brazil. The strains were isolated in defribinated sheep blood agar (5\%), incubated at $37^{\circ} \mathrm{C}$ for $72-96$ hours under aerobiosis. $R$. equi strains were classified based on macro and microscopical morphology, biochemical and cultural characteristics (Quinn et al., 1994). All strains were submitted to the standard minimal inhibitory concentration (MIC) of azithromycin $(0.016-256 \mu \mathrm{g} / \mathrm{ml})$, using a commercial kit (Etest $\left.^{\mathrm{TM}}\right)^{1}$, performed according to the manufacturer recommendations. Simultaneously, all strains were submitted to the standard disk diffusion method (Bauer et al., 1966) using azithromycin $(15 \mu \mathrm{g})$. MIC values were interpreted according to the Performance... (1999). R. equi strain (ATCC 33.701+) provided by Instituto de Biociências da UNESP Botucatu, SP, was used as control.

\footnotetext{
${ }^{1}$ E-Test - AB Biodisk - Dalvägen, Sweden.
} 


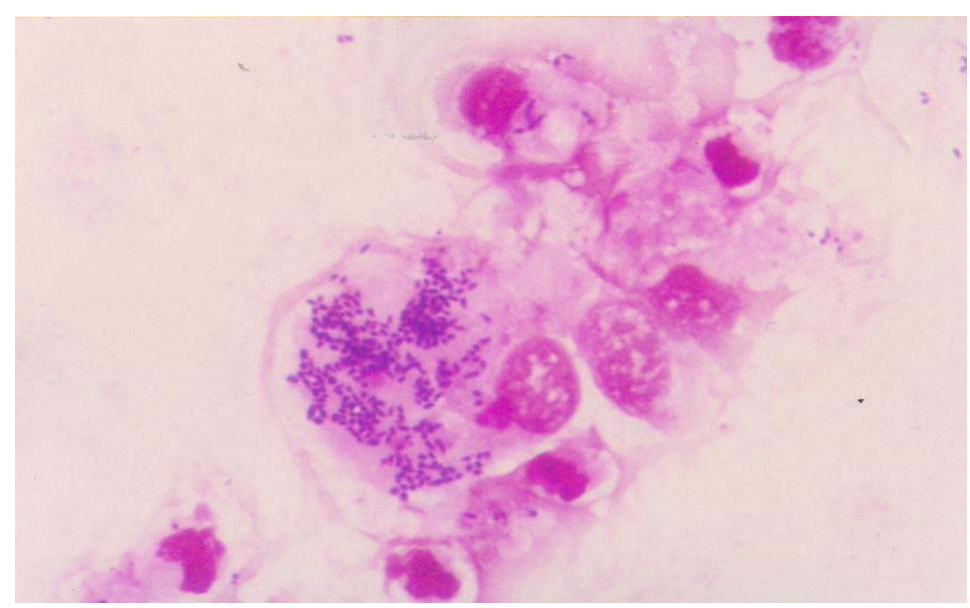

Figure 1. Numerous intracellular Gram-positive, coccal organisms, in alveolar macrophage from a foal with pyogranulomatous pneumonia caused by Rhodococcus equi. Botucatu, SP, 2004.

The $42 R$. equi isolates and the control strain were susceptible to azithromicin in the disk diffusion method $(\geq 18 \mathrm{~mm})$, based on the Performance... (1999). All the isolates and the control strain presented MIC values that demonstrated their susceptibility to azithromycin. The MIC in which $90 \%$ of the isolates were inhibited $\left(\mathrm{MIC}_{90}\right)$ by azithromycin was equal to $1.5 \mu \mathrm{g} / \mathrm{ml}$.

In Brazil, rhodococcosis is considered to be one of the most common disease of foals, causing severe chronic pyogranulomatous pneumonia and/or enteric signs, leading to high mortality rates. A recent study have demonstrated the high virulence of $R$. equi strains isolated from foals in Brazil (Ribeiro et al., 2005).

Despite of the efficacy of the rifampinerythromycin association for the treatment of $R$. equi infections in foals, different authors have reported concerns about the resistance of $R$. equi to these drugs (Precott and Sweeney, 1985; Giguère and Prescott, 1997; Ribeiro et al., 2002). Moreover, several complications have been reported with the long-term use of erythromycin in foals, including anorexia, hyperthermia, tachypnea, bruxism, colic and diarrhea (Giguère and Prescott, 1997; StrattonPhelps et al., 2000). Due to the undesirable collateral effects described in long-term use of rifampin and erythromycin, coupled with the development of resistant strains, other drugs have been studied as alternatives for the treatment of $R$. equi infections in foals, especially azithromycin.
Azithromycin is an antimicrobial of the macrolide group. It has several qualities, such as the possibility of oral and intravenous administration, high stability in acid $\mathrm{pH}$, high concentration in tissues and macrophages, lower incidence of gastrointestinal adverse effects, good oral bioavailability and broad spectrum against Gramnegative and mainly Gram-positive microorganisms, including $R$. equi strains from human and animal origins (Davis et al., 2002). Different treatment protocols have been investigated in vivo using azithromycin in foals infected by $R$. equi. The recommended dosage for azithromycin is $10 \mathrm{mg} / \mathrm{kg}$ every 24 hours, administered orally, for five days, followed by three other doses, every 48 hours (Becú, 1999).

In recent years, different in vitro studies have evaluated the susceptibility of $R$. equi strains isolated from foals using the disk diffusion method. However, few studies have investigated the minimal inhibitory concentration of the $R$. equi isolates (Jacks et al., 2003).

In Brazil, the in vitro susceptibility test of $39 R$. equi strains isolated from 37 pulmonar and two enteric infections in foals was performed, using the standard disk diffusion method. They showed $100.0 \%$ sensitivity to azithromycin (Ribeiro et al., 2001). Jacks et al. (2003) reported $\mathrm{MIC}_{90}$ in $64 R$. equi strains isolated from foals as equal to $1.0 \mu \mathrm{g} / \mathrm{ml}$. Similarly, in the present study, all the 42 isolates and the control strain were susceptible to azithromycin in the disk diffusion method, and showed a $\mathrm{MIC}_{90}$ value $\leq 1.5 \mu \mathrm{g} / \mathrm{ml}$, demonstrating the great effectiveness of azithromycin in Brazilian $R$. equi isolates. 
Results observed in the present study suggest that azithromycin can be an effective drug in the association with rifampin in rhodococcosis in foals and a possible alternative to erytromicin in the treatment of this infection.

Keywords: foal Rhodococus equi, azithromycin, minimal inhibitory concentration

\section{RESUMO}

O perfil de sensibilidade microbiana e a concentração inibitória mínima (MIC) da azitromicina para 42 cepas de Rhodococcus equi isoladas de potros, no Brasil, e em uma cepa-controle, foi avaliado, respectivamente, pelos métodos de difusão com discos e E-test. A azitromicina apresentou $100 \%$ de efetividade in vitro para todas as cepas em ambos os testes. As cepas de R. equi apresentaram MIC 90 $_{0}$ para azitromicina em valores $\leq 1.5 \mu \mathrm{g} / \mathrm{ml}$. Este estudo mostra a alta efetividade da azitromicina em linhagens de R. equi isoladas no Brasil, sugerindo o uso dessa droga como alternativa na terapia da rodococose em potros.

Palavras-chave: potro, Rhodococus equi, azitromicina, concentração inibitória mínima

\section{REFERENCES}

BAUER, A. W.; KIRBY, W. M. M.; SHERRIS, J. C. et al. Antibiotic susceptibility testing by a standardized single disk method. Am. J. Clin. Pathol., v.45, p.493496, 1966.

BECÚ, T. Rhodococcus. Rev. Saúde Eqüina, v. 2, p. 16-17, 1999.

DAVIS, J.L.; GARDNER, S.Y.; JONES, S.L. et al. Pharmacokinetics of azithromycin in foals after i.v. and oral dose disposition into phagocytes. J. Vet. Pharmacol. Ther., v.25, p.99-104, 2002.

GIGUÈRE, S.; PRESCOTT, J.F. Clinical manifestations, diagnosis, treatment, and prevention of Rhodococcus equi infections in foals. Vet. Microbiol., v.56, p.313-334, 1997.

JACKS, S. S.; GIGUÈRE, S.; NGUYEN, A. In vitro susceptibilities of Rhodococcus equi and other common equine pathogens to azithromycin, clarithromycin, and 20 other antimicrobials. Antimicrob. Agents Chemoth., v.47, p.1742-1745, 2003.

PERFORMANCE Standards for Antimicrobial Susceptibility Testing. 9.ed. Pennsylvania: National Committee for Clinical and Laboratory Standards, 1999. 104p.

PRESCOTT, J.F.; SWEENEY, C.R. Treatment a Corynebacterium equi pneumonia in foals: a review. $J$. Am. Vet. Med. Assoc., v.187, p.725-727, 1985.

QUINN, P. J.; CARTER, M. E.; MARKEY, B. et al. Clinical Veterinary Microbiology. London: Wolfe, 1994. 648p.

RADOSTITS, O.M.; BLOOD, D.C.; GAY, C.C. Veterinary Medicine: a textbook of the diseases of cattle, sheep, pigs, goats and horses. 8.ed. Philadelphia: Baillière Tindall, 2000. p.881-884.
RIBEIRO, M.G.; NARDI JÚNIOR, G.; DIAS JÚNIOR, J.G. et al. Polissinovite auto-imune por Rhodococcus equi em potro, secundária à enterocolite. Rev. Educ. Contin. CRMV-SP, v.5, p.206-214, 2002.

RIBEIRO, M.G.; SEKI, I.; YASUOKA, K. et al. Molecular epidemiology of virulent Rhodococcus equi from foals in Brazil: virulence plasmids of 85-kb type I, 87-kb type I, and a new variant, 87-kb type III. Comp. Immunol. Microbiol. Infect. Dis., v.28, p.53-61, 2005.

RIBEIRO, M.G.; NARDI JÚNIOR, G.; PAES, A.C. et al. Susceptibility in vitro of Rhodococcus equi strains isolated from foals to azithromycin. In: CONGRESSO BRASILEIRO DE MICROBIOLOGIA, 21., 2001. Foz do Iguaçu, Anais... Foz do Iguaçu, 2001. p.185.

SEVERO, L.C.; RITTER, P.; PETRILLO, V.F. et al. Infecção pulmonar por Rhodococcus equi: relato dos dois primeiros casos brasileiros. J. Pneumol., v.27, p.158-162, 2001.

STRATTON-PHELPS, M.; WILSON, W.D.; GARDNER, I.A. Risk of adverse effects in pneumonic foals treated with erythromycin versus other antibiotics: 143 cases (1986-1996). J. Am. Vet. Med. Assoc., v.217, p.68-73, 2000.

TAKAI, S. Epidemiology of Rhodococcus equi infections: A review. Vet. Microbiol., v.56, p.167-176, 1997.

TAKAI, S.; MARTENS, R.J.; JULIAN, A. et al. Virulence of Rhodococcus equi isolated from cats and dogs. J. Clin. Microbiol., v.41, p.4468-4470, 2003.

TAVARES, W. Manual de antibióticos e quimioterápicos antiinfecciosos. 3.ed. São Paulo: Atheneu, 2002. 1216p. 